\title{
Education and the Task of Deconstructing the History of Ontology
}

\author{
A educação e a tarefa de desconstruir a História da \\ Ontologia
}

Paulo Eduardo Lopes da Silva ${ }^{1}$

\begin{abstract}
Throughout the history of Ontology, the comprehension of Being has often deviated from its original path and taken different directions. What are the consequences of this detour when it comes to the current conception about the phenomenon we call Education? From the Fundamental Ontology of Martin Heidegger until the considerations of other contemporary thinkers, this article proposes an involvement and commitment regarding the task of deconstructing the history of Ontology in order to enable an approach that unveils the most original essence of Education as raı $\delta \varepsilon i a$. This is the challenge that concerns all those who somehow confront the questions related to everydayness and the possibility of Dasein to find its truth even in face of the dictatorship of the 'they' (das Man). Therefore, the aim of these reflections is to offer a new and introductory perspective that can open a horizon of projects in which we become transparent to ourselves in our resoluteness (Entschlossenheit).
\end{abstract}

Keywords: Education. Fundamental Ontology. Martin Heidegger.

\section{Resumo}

Ao longo da história da Ontologia, a compreensão do Ser muitas vezes se desviou de seu caminho original e tomou diferentes direções. Quais são as consequências desse desvio no que se refere à concepção atual sobre o fenômeno que chamamos de Educação? Desde a Ontologia Fundamental de Martin Heidegger até as considerações de outros pensadores contemporâneos, este artigo propõe um envolvimento e um compromisso quanto à tarefa de desconstruir a história da Ontologia de forma a possibilitar uma abordagem que desvenda a essência mais original da Educação como $\pi \alpha \iota \delta \varepsilon i \alpha$. Este é o desafio que preocupa todos aqueles que de alguma forma se confrontam com as questões relacionadas com a cotidianidade e a possibilidade do Dasein encontrar a sua verdade mesmo em face da ditadura do 'eles' (das Man). Portanto, o objetivo dessas reflexões é oferecer uma perspectiva nova e introdutória que pode abrir um horizonte de projetos nos quais nos tornamos transparentes para nós mesmos em nossa determinação (Entschlossenheit).

\footnotetext{
Doutorado em Filosofia na Pontifícia Universidade Católica do Paraná e professor de Psicologia e Filosofia
} 


\section{Introduction}

Nowadays, Education has certainly been a broad theme widely discussed by many philosophers and other researchers all over the world. It can be told from the variety of published books and articles whose purpose is to reflect on this particular issue in an attempt to find some answers to questions such as: what is the essence of Education? What is the meaning of it? Is Education a matter of priority above any other? What is learning? What is teaching? How do children learn? Are there different kinds of Education? Is technology for or against it?

Not as evident as they may seem, the replies to those inquiries are far from being easily or quickly found. Since the dawn of philosophical thought, we have tried to catch at least a glimpse of what Education as a phenomenon means to be. Hitherto we have just begun to unravel the puzzles of it, keeping the most of its mysteries untouched by the light of our limited comprehension.

Nevertheless, much more than a theme, Education is in itself an ontic experience, a possibility that belongs to all of us, as long as we exist together. It is our destiny once we can only be who we genuinely are through its path. From such a perspective, we should not be considered as the 'result' of a 'process' called Education. This simply refers to a particular mechanised conception of Education born out of the technicism, which dictates terms to the contemporary world. Moreover, this is the danger Heidegger (1977b) mentions in The Question Concerning Technology, a danger that constantly threatens us all, throwing away into the oblivion our most authentic possibilities as Dasein.

Instead of a 'process', Education urges to be phenomenologically apprehended as a mode of being-in-the-world with each other. In this case, 
Education is not only the path, but also the journey, the movement towards the unknown - or the untruth (Unwahrheit) as Heidegger (1998) calls it.

Actually, Education is the experience of $\pi \alpha l \delta \varepsilon i \alpha$ in the most profound sense of the Greek expression.

Relying on Plato's allegory of the cave, Heidegger states that Paideia is a movement of passage. What does he mean by the term 'a movement of passage'? The answer is found in the movements of the person described in the allegory of the cave. When undergoing Paideia, Heidegger explains, the soul turns its entire essence toward a new realm of beings that have partially become unconcealed and seeks for truths that can be found in this realm. Need we add that such a turning of one's soul toward a new realm is rarely the case in what is currently called education? (Gordon; Gordon, 2007, p. 51).

If we, for instance, contemplate babies or small children, we will clearly see that, even before the attainment of rational and theoretical knowledge about facts, they are all the time discovering a 'new realm'. It is no wonder that the Greek term $\pi \alpha l \delta \varepsilon i \alpha$ etymologically derives from $\pi \alpha l \delta i$, which literally means child.

To be more accurate, undeniable is the fact that, from birth to death, we all, as Dasein, are unveiling the world and this is the foundation of the possibility of an educational experience as well as the possibilities of both learning and teaching. Due to this, knowledge can only be related to Education secondarily, that is, in a derivative way.

Based on Kant's thought, Heidegger (1997) states that our knowledge cannot create anything. Otherwise, our knowledge just welcomes the entities in the unconcealment of the world. In other words, knowledge is just an expression of the most original disclosedness (Erschlossenheit). The same ought to be true when it comes to any experience, including Education, because experience is receptive - and finite - intuition (Anschauung) that has to let one's being manifests itself. 
However, as Being-towards-death, it is not possible for us to reach omniscience. Our knowledge is, alongside intuition, essentially finite. The temporality (Zeitlichkeit) of being-in-the-world as care (Sorge) constitutes the finitude of knowledge. We originally are this $\dot{\alpha} \lambda \dot{\eta} \theta \varepsilon l \alpha$, this constant and finite movement of re-vealing meanings, illuminating the Being and, at the same time, maintaining it in concealment. This is the ground upon which Paulo Freire $(2001 ; 2018)$ could understand learning and teaching as the own human condition of inconclusiveness and indeterminacy. That fits in with what Heidegger $(1962 ; 2001 ; 2006)$ says about the problem of defining Dasein as object or substance.

Rather, to exist as Da-sein means to hold open a domain through its capacity to receive-perceive the significance of the things that are given to it [Dasein] and that address it [Dasein] by virtue of its own "clearing" [Gelichtetheit]. Human Da-sein as a domain with the capacity for receiving-perceiving is never merely an object present-athand. On the contrary, it is not something which can be objectified at all under any circumstances (Heidegger, 2001, p. 4).

We are definitely our finite possibilities and this is precisely what summons us to our ownmost Being-guilty. However, it should be clarified that, by the term guilty, we do not refer to any kind of morality. It has nothing to do with being in debt with someone else and much less means that we have done something 'wrong'. This guilt is not even a fault that sometimes does lie with us and sometimes does not. This is much more original than that. When, in resoluteness (Entschlossenheit), we anticipate the possibility of death, we also embrace our finitude with the serenity of those who are constantly in debt with themselves in face of the primary existential task of realising their authentic Being. Thus, the phenomena of irresoluteness and resoluteness are equally original in the Being constitution of Dasein. 
[...] Dasein is equiprimordially in the untruth. Anticipatory resoluteness gives Dasein at the same time the primordial certainty that it has been closed off. In anticipatory resoluteness, Dasein holds itself open for its constant lostness in the irresoluteness of the "they" a lostness which is possible from the very basis of its own Being. As a constant possibility of Dasein, irresoluteness is co-certain. When resoluteness is transparent to itself, it understands that the indefiniteness of one's potentiality-for-Being is made definite only in a resolution as regards the current Situation (Heidegger, 1962, p. 356).

Furthermore, if Education is $\pi \alpha l \delta \varepsilon i \alpha$ and $\pi \alpha l \delta \varepsilon i \alpha$ is turning oneself towards a new realm in order to look for the truth, then such a turning is in itself the disclosedness of the essential Being-guilty. Put the matter another way, we could say that seeking for the truth of the world proves to be the same as seeking for our own truth. In this movement, death, as our last, inevitable, unsurpassed and certain possibility, is the one that ends our finite indeterminacy. Paradoxical as it may be, our indefiniteness is not founded upon the possibility that we will be forever, but exactly the opposite. In educational terms, our inconclusiveness does not signify that we can learn forever. Differently, it means that learning is a possibility that will belong to us until we die.

2. The meaning of education as $\pi \alpha l \delta \varepsilon i \alpha$ : phenomenological contributions

As the $\pi \alpha l \delta \varepsilon i \alpha$ experience, Education does not necessarily occur in predetermined places. In fact, it can happen everywhere. Notwithstanding, the resolution to leave the cave and break new ground is not merely 'subjective'. Instead, it is a response to the requests of being-in-the-world. And not any kind of response, but a quite particular one: a response that follows the call of conscience (der Ruf des Gewissens) and rescue the Being-guilty, witnessing an authentic existentiell possibility. This is the most original educational experience. 
At schools, for example, we can enable genuine educational experiences $(\pi \alpha l \delta \varepsilon i \alpha)$ by challenging the children and letting them be according to their most authentic possibilities. Of course, it is not as simple as it seems to be. Regularly, we are so immersed and lost in the publicness of the 'they' (das Man) that we cannot find ourselves. Most of the times, in our solicitude (Fürsorge) we are 'leaping in' for the others, promptly telling them what they are supposed to do instead of questioning. Very often, we give them answers for everything, forgetting - and, in some cases, avoiding

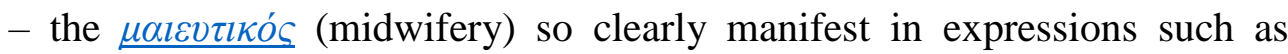
'What do you think of it?' or 'May we discover it together?'.

We rarely experience the authentic solicitude in which, as Heidegger (1962; 2006) states, we help the Other to become transparent to himself in his care and to become free for it. In spite of this, we have evidences that small children, mainly babies, can preserve the $\pi \alpha l \delta \varepsilon i \alpha$ experience in all its breadth and depth. The point is that the longer we stay in the cave the harder it becomes to exit from it later. Plato (2018) himself could not forget to give us the detail about how tough and even confusing it is for the one who gets out of the cave to deal with the true beings of the realm outside that show themselves up in the sunlight.

After all, we already know that it is not impossible to open up opportunities that encourage the sense of responsibility and presents a path through which Dasein can broaden its horizons and decide for the authentic potentiality-for-Being (Seinkönnen).

An education based on a Heideggerian Philosophy of Education gives us only the opportunity to experience the possibility of becoming free from the everyday immediacy, facing the urge to choose our own direction and decide on occupations that are necessary to the fight for being singulars in the world. This resolution (unique and in accordance with the most relevant meanings of Being-in-the-world) would set us apart from the they-self, making us emerge as authentic existence (Kahlmeyer-Mertens, 2008b, p.220-221, our translation). 
In this sense, the philosophical task of deconstructing (Destruktion) the history of Ontology directly concerns Education since we frequently abandon the Being by insisting on staying in the 'cave' of traditional metaphysics. As an example, we could mention how quickly we misunderstand Education when we think of it through the method proposed by Descartes (2006), including his definitions of human being as res cogitans and world as res extensa, both considered as substances, that is, entities that do not need any other in order to be. A very common misconception about Education that, without being questioned, derives from the idea of substantiality is the one Paulo Freire $(2001$; 2018) permanently criticises in his works: 'teaching is all about transferring knowledge'. We hardly ever take into account that this dangerous statement only feeds the power-based relations and darkens the shadows of verticality in the school context. In Being and Time, Heidegger (1962; 2006) asserts that communication is never the transposition of experiences, such as opinions, from the interior of one 'subject' into the interior of another. Dasein-with is already essentially manifest in a co-understanding; hence the expression 'learning with someone' is much more congruous than the expression 'learning from someone'.

In the $\pi \alpha l \delta \varepsilon i \alpha$ experience, we are re-vealing the world together and this opens for us the possibility of learning and teaching simultaneously and constantly. The formal categories of 'teacher' and 'pupil', 'professor' and 'students' cannot be ontically experienced unless we neglect the fact that, as Paulo Freire (2001) says, we equally teach when we are learning and we equally learn when we are teaching.

According to Kahlmeyer-Mertens (2008b), when our comprehension about Education is subtly based on the 'they' (das Man), it just enables the reproduction of an inauthentic existence. Such an 'Education' is the smithy in which behaviours are forged and subjugated by a set of guidelines established by an invisible consensus. This, with the authority of something consecrated by repetition, accommodates itself by instituting habits, customs, and inducing its acceptance as a common sense standard, creating 
then identities and distinctions, groupings and segregation, valuations and hierarchies that we can observe in the way societies are structured and relations are 'combined'.

The problem of objectifying Dasein becomes even more perilous when we turn Education into a 'substance' that can be quantified. How easily we overestimate the measurement of 'performances' as well as the calculation of results. How confident we are about statistics, proximally and for the most time accepting its verdict and inadvertently ignoring Dasein's indefiniteness. By doing so, we walk further and further from Education's essence, dissolving ourselves in the kind of Being of everydayness (Alltäglichkeit) and keeping the dictatorship of the 'they' (das Man) with its own ways in which to be, namely the averageness (Durchschnittlichkeit) and the 'levelling down' (Einebnung) of all possibilities of Being. Not to mention, in this plot, the use of uniforms in schools whose function is to forthwith flatten the singularities and flee from the challenges that inevitably arise from the existential fact that we are different from each other, phenomenon Heidegger $(1962 ;$ 2006) calls distantiality (Abständigkeit).

In one's concern with what one has taken hold of, whether with, for, or against the Others, there is constant care as to the way one differs from them, whether that difference is merely one that is to be evened out, whether one's own Dasein has lagged behind the Others and wants to catch up in relationship to them, or whether one's Dasein already has some priority over them and sets out to keep them suppressed. The care about this distance between them is disturbing to Being-with-one-another, though this disturbance is one that is hidden from it. If we may express this existentially, such Being-with-oneanother has the character of distantiality [Abständigkeit]. The more inconspicuous this kind of Being is to everyday Dasein itself, all the more stubbornly and primordially does it work itself out (Heidegger, 1962, p. 163-164). 
Despite all of this, there is still some hope left. Viktor Frankl (1976), for instance, enlightens us with his phenomenological elucidations concerning Education, mainly when he points out that, more than ever, Education is Education towards responsibility. He also affirms that we live in a society of overabundance, which is not only of material goods, but also of information, an explosion of information. If we want to survive before this flood of stimuli brought by the mass media, we need to know what is important and what is not important for us, what is essential and what is not essential. In other words, what makes sense and what does not.

According to its essence, Education always emanates from the project (Entwurf) that constitutes us as Dasein. The foundation of Education is our ontological disclosedness in its most peculiar possibility.

To Dasein's state of Being belongs projection: disclosive Being towards its potentiality-for-Being. As something that understands, Dasein can understand itself in terms of the 'world' and Others or in terms of its ownmost potentiality-for-Being. The possibility just mentioned means that Dasein discloses itself to itself in and as its ownmost potentiality-for Being. This authentic disclosedness shows the phenomenon of the most primordial truth in the mode of authenticity. The most primordial, and indeed the most authentic, disclosedness in which Dasein, as a potentiality-for-Being, can be is the truth of existence. This becomes existentially and ontologically definite only in connection with the analysis of Dasein's authenticity (Heidegger, 1962, p. 264).

In this direction, Education is the same as that resoluteness (Entschlossenheit) towards the truth of existence. Education is all about making my choice instead of the Others. Not a theoretical (rational) choice, but an existential and more original choice that is action, the action of building my own path. Except for me, no one else is responsible for this decision. 
Our questions now are the following: how could Education endure? How could it survive under the waves of everydayness? We can still see the persistence of the $\pi \alpha i \delta \varepsilon i \alpha$ experience in the phenomenon of art, for example.

Actually, art is in itself $\pi \alpha l \delta \varepsilon i \alpha$. In all its genuine expressions, art has been the only survivor in the war against the differences. Indeed, it is a peculiar experience of freedom. In The Origin of the Work of Art, Heidegger (1977a) mentions that art is the truth setting itself-into-works (das Ins-WerkSetzen der Wahrheit), that means, art is the truth manifestation. In the work, art makes the truth of beings arise. As a matter of fact, art is a mode how the truth happens historically.

Thus, we should ask why art generally has too little room in our schools and universities. Perhaps because it is more convenient to respond to the expectations of the 'they' (das Man) instead of throwing ourselves into the uncertainty we ourselves are as Dasein. For sure, becoming artists demands much more from us. Not because it is definitely a step in the dark, but because it is a courageous step towards the light.

\section{Conclusion}

In his work entitled Pedagogy for Uneducated Children (our translation), Reguera (2010) affirms that what has always been a necessity, the need to prepare for life, we interpret as a right, namely the 'right' to Education. We do this without warning ourselves of the devaluation and juridical reductionism that this implies since a necessity belongs to a range that is wider, more natural and more imperative than a right. After, we devalue the 'right' to Education as 'obligation' to be educated, subtle transition from the right to demand to the duty to obey.

We could not fail to add that, even worse than this, currently and frequently we have been misconceiving Education as 'merchandise'. We have turned our essential Dasein-with into business relations based on purchasing power. In this case, Education comes to be no longer an 
'obligation' but one of the 'consumer goods' which only the economically privileged social minority can have access to.

In the history of Ontology, Being has been left in oblivion and, consequently, Education as well. As Colpo (2002) states, Education should be originally understood as the possibility for Dasein, during its existence, to do the exercise of inquiring about the meaning of what is presented to it, which becomes a question about itself, about its own existential situation. Such a possibility enables the condition for Dasein to be able to situate itself in its existence, unconcealing true contexts of relationships and projects for itself. Only open to its potentiality-for-Being Dasein can respond to the requests of what calls it as the task, or perhaps better said, the fight for finding its authenticity.

\section{References}

COLPO, Marcos. O. Fundamentos para uma Filosofia da Educação a partir da Ontologia de Martin Heidegger. 2002. 259 páginas. Dissertação de Mestrado em Filosofia - Universidade de São Paulo, São Paulo.

DESCARTES, René. A Discourse on the Method. Oxford: Oxford University Press, 2006.

FRANKL, Viktor Emil. The Unconscious God. New York: Pocket Books, 1976.

FREIRE, Paulo. Pedagogy of Freedom: Ethics, Democracy and Civic Courage. Lanham: Rowman \& Littlefield Publishers, 2001.

FREIRE, Paulo. Pedagogy of the Oppressed. New York: Bloomsbury Academic, 2018.

GORDON, Haim; GORDON, Rivca. Heidegger on Truth and Myth: A Rejection of Postmodernism. New York: Peter Lang, 2007.

HEIDEGGER, Martin. Being and Time. Oxford: Blackwell, 1962. 
HEIDEGGER, Martin. Der Ursprung des Kunstwerkes. In:

Gesamtausgabe - I. Abteilung: Veröffentlichte Schriften 1914-1970 - Holzwege. Frankfurt: Vittorio Klostermann, 1977a. p. 1-74. (Band 5).

HEIDEGGER, Martin. The Question Concerning Technology and Other Essays. New York: Harper and Row, 1977b.

HEIDEGGER, Martin. Kant and the Problem of Metaphysics. Bloomington: Indiana University Press, 1997.

HEIDEGGER, Martin. Pathmarks. Cambridge: Cambridge University Press, 1998.

HEIDEGGER, Martin. Zollikon Seminars: Protocols, Conversations, Letters. Evanston: Northwestern University Press, 2001.

HEIDEGGER, Martin. Sein und Zeit. Tübingen: Max Niemeyer Verlag, 2006.

KAHLMEYER-MERTENS, Roberto. Heidegger e a Educação. Belo Horizonte: Autêntica, 2008b.

PLATO. The Republic. New York: Basic Books, 2016.

REGUERA, Henrique. Pedagogía para Mal Educados. Madrid: Editorial Popular, 2010.

Submetido em: $24 / 08 / 2020$

Aceito em: 27/04/2021

Publicado em: 12/05/2021 